\title{
CHANGES IN THE INCOME SITUATION OF AGRICULTURAL HOLDINGS IN THE LIGHT OF THE POLISH FADN OBSERVATIONS FROM 2004-2018
}

\author{
JACEK KULAWIK \\ RENATA PŁONKA \\ BARBARA WIELICZKO
}

\begin{abstract}
The income of farmers and their families is the base for consumption, savings, and investment. However, apart from its level and adequate ratios to the income of the agricultural population, its stability is also important. This very thesis is the main axis of the analysis of the income situation of Polish farmers participating in the FADN from 2004 to2018. Its documentation is also one of the main aims of this paper. To do this from the right theoretical perspective, theinitial part of the paper presents the schemes of this income calculation and its determinants, as well as issues related to measuring income risk and the factors which affect it. Both static and dynamic approaches were used in this part of the paper. The other, thoroughly empirical and retrospective part of the paper focuses on the relationships between income and budget support, economic size, production type, and spatial location of agricultural farms. The importance of non-agricultural income was also shown, although relevant information in the FADN is not very extensive. The identification of the risk-income strategy should also be treated as a preliminary approach to the analyzed issue.
\end{abstract}

Keywords: agricultural income, agriculture, income risk.

JEL codes: Q10, Q12,Q14, Q18.

\footnotetext{
Jacek Kulawik, PhD, DSc, ProfTit, Institute of Agricultural and Food Economics - National Research Institute, Department of Finance and Risk Management; ul. Świętokrzyska 20, 00-002 Warsaw, Poland (jacek.kulawik@ierigz.waw.pl). ORCID iD: 0000-0001-8731-1765.

Renata Płonka, MEng, Institute of Agricultural and Food Economics - National Research Institute, Department of Agricultural Holdings Accountancy, ul. Świętokrzyska 20, 00-002 Warsaw, Poland (Renata.Plonka@ierigz.waw.pl). ORCID iD: 0000-0001-8643-5985.

Barbara Wieliczko, PhD, DSc, Assoc. Prof. of IAFE-NRI, Institute of Agricultural and Food Economics National Research Institute, Department of Finance and Risk Management; ul. Świętokrzyska 20, 00-002 Warsaw, Poland (Barbara.Wieliczko@ierigz.waw.pl). ORCID iD: 0000-0003-3770-0409.
} 


\section{Definition and classification issues}

In the broadest sense, income in micro- and macroeconomics can be understood as the creation of financial opportunities by particular entities and entire societies to meet consumption and development needs at a specific time. To accomplish this goal, it is necessary to involve production inputs, i.e., labor, land, physical, and financial capital, and human entrepreneurship in properly organized farming processes. It must be added straightaway that entrepreneurship is associated with risk, and the ability to take it is, according to H. W. Sinn, even a separate production input (Sinn, 1986). In turn, the consequence of the use of production inputs is the expectation that they will yield specific remuneration, in the form of rent, wages, interest rates, and entrepreneurial profits. Therefore, the income is in this case the sum of the above-mentioned inputs. Hence, it is sometimes referred to as gross income. Income understood in this way therefore integrates its productive and redistributive functions (Woś, 1998, 1987). It is thus evident that income in the economy is a kind of surplus and, at the same time, a residual amount, created by reducing revenue by certain costs to obtain net income.

More specifically, the net income of entities with a legal personality becomes their financial result, which is further transformed into taxable income, while in financial management, it can be transformed into cash income, that is very often equated with cash flow, with an option for its further disaggregation.

In microeconomics, and more specifically in consumer theory, income is often presented as a budget limitation of an entity or a household. This leads us directly to the issue of demand development. If, however, the analysis is to be conducted in multiple periods, the income is sometimes replaced with assets, i.e., in the form of part of its cumulative value. At this point, specific categories of income emerge again, such as permanent income. In this context, in economics, and not only in this scientific discipline, great importance is attached to issues related to income growth and its distribution.

In the Polish tradition of agricultural economics, agricultural income, calculated as the difference between global output and material input, is defined as the global income, which represents the value of net output. Indeed, it has an equivalent in newly manufactured goods and services provided. Net output is, in turn, divided into remuneration for work and other income, called net income, financing, among others, development goals. In the case of farms run by natural persons, off-farm income added to general income is the personal income of a farming family, which is spent on consumption and accumulation. The personal income category will be dealt with in a nutshell later on. Farmers' disposable income, surveyed by the Polish Central Statistical Office (GUS) (Grzelak, 2016), will not be analyzed at all. The overall focus will be on income from the family farm, determined as part of the Polish FADN, whose formula will be presented later in the paper. 


\section{Income risk, its measurement, and determinants}

The level of agricultural income and its distribution, i.e., income risk, integrates historical production risk, correlations between prices and yields, that, when negative enough, lead to natural hedging, price risk, and production costs (Walters, Preston, 2018). Income risk can be reduced firstly by insuring crops (protection against production risk), revenue (reducing production risk and, partially, also price risk), and hedging with futures and options. It must be added at this point that it is the income risk that is reduced the most, through the purchase of revenue insurance. The use of these two types of instruments implies, however, the emergence of substitutability and complementarity relations, but still some part of income risk remains uncovered, which is referred to as basic economic risk (Binswanger-Mkhize, 2012). This circumstance, in an extreme situation, may result in the bankruptcy of the agricultural holding/agricultural enterprise.

C. Walters and R. Preston analyzed, using a combination of the modern portfolio approach and Monte Carlo simulation, the relationships between the net income level and risk and insurance and future transactions on the example of a representative farm. The above $N I$ income has been determined as follows:

$$
N I=p \times y_{r}-b-c(y)+I\left(r, r^{*}, z\right)-d(z)+p_{h} \times y_{h}-h c+\text { buyback, }
$$

where: $p$ - crop price at the time of harvest; $y$-current yield; $b$ - fixed production costs; $c(y)$ - other production costs; $I\left(r, r^{*}, z\right)-d(z)$ - damages function, where $r$ is current revenue, $r^{*}$ is guaranteed income, $z$ is the characteristics of the insurance policy, $d(z)$ - insurance premium; $p_{h} \times y_{h}$ - hedging contract concluded before harvest, where $p_{h}$ is the price of the hedged crop and $y_{h}$ is the quantity of the hedged crop; $h c$ - is the total cost of hedging; buyback is the financial expression of output lower than the one hedged.

In the portfolio method, the most favorable combination (effective portfolio) between some result category or in the area of profitability and the risk measure is usually sought. In the case of an analysis using the Walters and Preston method, the outcome was the above-mentioned net result, while the downside risk was a measure of risk, and more specifically, the probability of the farm's bankruptcy (expected loss). The farmer's goal is now to select a portfolio that will minimize the financial effect of the expected $1 \%$ loss, which is tantamount to an $82 \%$ probability of success or an $18 \%$ probability of a $1 \%$ loss.

Finally, let us summarize briefly the key conclusions of the Walters and Preston analysis:

1. Measurement of income risk is not trivial. Following the two above-mentioned American agricultural economists, one can try to integrate historical information about yields, current prices in futures contracts, and correlations between actual relations between yields and prices in specific farms. 
2. Only insurance of income with the greatest coverage levels, i.e., $80 \%$ and $85 \%$, was on the verge of effectiveness, while hedging on the verge of effectiveness was in a very wide range: $0-55 \%$ of the current yield history. A $5 \%$ increase in coverage (from $80 \%$ to $85 \%$ ) in the case of revenue insurance was correlated with a decrease in optimal hedging by as much as 25 percentage points (from $35 \%$ to $9 \%$ ). It can be seen that insurance has a positive effect on the economics and finances of farms, as it allows the release of working capital, e.g., for investment or consumption purposes, but the measurement of this effect still remains a challenge.

3. Insurance and hedging decisions should be handled jointly. In the examined farm, geared towards growing maize for grain, the following rule was followed: higher insurance coverage meant lower optimal hedging in extreme situations even valued at zero. Moreover, by subsidizing insurance premiums, the expected net income increased along with the increase in coverage. It comes as a surprise, however, that hedging without insurance led to an increase in revenue risk and financial risk, which is supposed to result from the complex cost structures of this instrument. This finding is clearly contradictory to the prevailing view that hedging always reduces risk.

Different types of farm characteristics determine the variability of their income and revenue. The following characteristics are usually analyzed in this respect:

1. The degree of dependence on direct payments. Generally, there is a consensus that their relative stability, or even independence from risk, stabilizes agricultural income (El Benni, Finger, and Meuwissen, 2016). However, it should always be remembered that their complete risklessness is a simplification. Firstly, this support is sometimes received by farmers with some delay, but sometimes it may be cumulated, which may reduce the effectiveness of its use. Secondly, this aid is not unconditional, the most advanced form of which has been an attempt to "green" these payments in the EU. Thirdly, there is a tendency in the CAP to couple them with agricultural production, which will also affect farmers' behavior in various ways, especially in terms of risk management. It may then happen that although the income risk will decrease, income volatility will increase.

2. The size of the farm. The standard assumption is that economies of scale increase production efficiency, which is supposed to increase resistance to shocks and extreme events (Barry, Escalante, and Bard, 2001). At the same time, smaller farms more often generate more stable non-agricultural income, which subsequently reduces the volatility of the income of entire households. However, on larger farms, there is a much greater chance that natural hedging will be in place, and thus there will be an imperfect correlation between the yields of particular crops. As a result, their production risk may decrease.

3. Stability of resources of some production inputs. This leads to a greater burden on farms with fixed costs, which will usually result in greater volatility of their income. 
4. Spatial location. This factor is closely related to the variability of the natural and soil conditions, which has an obvious impact on production, revenue, and income risks. For researchers, this circumstance means, among others, the need to develop models for various types of farms and their operating conditions.

5. Specialization and production type. There are usually two opposite relationships in this respect. Firstly, specialization most often leads to economies of scale, which - as mentioned earlier - increase resistance to various types of threats. On the other hand, higher specialization may lead to greater risk exposure (Poon and Weersink, 2011). This also applies to a large extent to production types identified based on aggregate specialization.

In Ireland, it was found that the volatility of income of farmers' households from 2006-2012 was clearly higher than the corresponding ratios for non-farmers' rural households and urban households (Loughrey and Hennesy, 2016). This circumstance should be treated as a factor reducing the welfare of farming families, which often occurs when their income is lower in absolute terms than that of nonagricultural workers. The problem is further complicated by the fact that, for example, in EU agriculture, the set of short-term income risk management instruments is poorer than that in the USA or Canada. As a result, European farmers often have to keep high levels of prudential savings or are over-indebted, which ultimately also reduces their welfare. In these conditions, it is much more difficult to optimize the portfolio of risk management instruments in the EU. Last but not least, the high volatility of agricultural income may discourage farmers from investment.

The two above-mentioned Irish agricultural economists approached the issue of measuring agricultural income volatility in a very interesting way, distinguishing a short-term (up to one year) perspective and medium-term (up to 9 years) one, based on data provided by 911 farms in the Irish FADN for 2005-2013, i.e., after the decoupling of direct payments under the CAP. In this approach, the total gross income of the farm, i.e., including direct payments less fixed costs, was taken into account. By the subsequent deduction of the above payments from this income, the combined gross income was obtained. It was also noted that fixed costs showed slightly lower volatility than the direct ones. This should not come as a great surprise, given that the former are usually constant and independent of the output volume, while the latter are variable costs. Table 1 clearly shows that combined income is much more volatile in the medium-term than gross income. This shows how big the impact of direct payments on income stability is, although this support may also significantly reduce/displace farmers' interest in other income risk management instruments. It is also worth noting that combined income is characterized by much more profound differences in the coefficient of variation between production directions than in the case of gross income. It needs to be noted that Loughrey and Hennessy used one more medium-term measure of income volatility, i.e., its standard deviations. 
Table 1

Average median of the volatility coefficient on Irish farms from 2005-2013

\begin{tabular}{lcc}
\hline \multicolumn{1}{c}{ Production direction } & Gross income & Combined income \\
\hline - cattle & 24.42 & 52.35 \\
- dairy cows & 21.08 & 26.33 \\
- field crops & 18.50 & 32.70 \\
- sheep & 19.43 & 37.11 \\
- other cattle & 20.52 & 32.75 \\
Average & 22.12 & 39.19 \\
\hline
\end{tabular}

Source: own study based on: Loughrey and Hennessy (2016).

Two measures were used also for short-term income volatility:

1. Percentage change compared to the previous year.

2. Removal of the trend from data characterizing only combined income.

The difference between the actual income and the projected income was then estimated. By dividing this difference by the latter income, a fractional deviation that is a measure of volatility/risk - is ultimately achieved. It is actually a quite complex procedure that was intentionally included in the appendix to the main content of the paper. This procedure is necessary to avoid overestimating income volatility, which is indispensable if, for example, the EU income stability tool (IST) is to be implemented, and to make correct actuarial estimations of insurance rates and public support.

It was indisputably R. Jones in 1969 who initiated major research into the stability of agricultural income (Jones, 1969). His main interest was its development in comparison to non-agricultural income in the United Kingdom and the USA, and the time series covered 1937-1965. Generally speaking, the analysis carried out by Jones showed that the volatility of agricultural income was twice as high as the corresponding indicators for the non-agricultural sector. Later studies, such as that carried out by A. Mishra and C. Sandretto in 2002, showed a further increase in the volatility of agricultural income and its reciprocal impact on the entire national economy. Of course, in highly developed countries, where agriculture now plays a minor role, e.g., in generating GDP, such an impact should not be overestimated. It is also necessary to be aware that the introduction of decoupled direct payments may make it difficult to recognize the relationships between agricultural income and its economic determinants. The latter typically include: prices paid by farmers, prices received by them for products sold, exchange rate, interest rates, GDP growth, and technological shocks, e.g., in the form of changes in synthetic indices of productivity. The above-mentioned macroeconomic categories may have various effects on agricultural income in equilibrium, and at the same time, are a source of its additional volatility. Hence, agriculture is often referred to as a sector susceptible to boom and bust cycles (Boehlje, Gloy, and Henderson, 2013). 
In 2015, J. Beckman and D. Schimmelpfenning published a paper where they state directly in the introduction that they want to verify the assumptions and results of the research carried out by R. Jones, adopting, however, as the initial equation of agricultural income, the one formulated by J. Baek and W. Koo in their paper entitled The US Agricultural Sector and the Macroeconomy, published in 2010. The equation is as follows:

$$
\text { agricultural income }_{t}=f\left(P_{t}, G D P_{t}, E R_{t}, I R_{t}\right) \text {, }
$$

where: $P$ - the ratio of prices received to price paid, GDP - GDP in fixed prices, $E R$ - exchange rate, $I R$ - interest rate, $t$ - time. Then, Beckmann and Schimmelpfenning (2015) discuss in detail the above formula, ultimately extending it and transforming it into an income/profit function at a single farm level $\pi^{t}$ :

$$
\pi^{t}=f\left(P R^{t}, P P^{t}, T F P^{t}, I R^{t}, E R^{t}, G D P^{t}, L P^{t}\right),
$$

where: $P P$ - price paid by farmers, $P R$ - price received by farmers, $T F P$ - total factor productivity in agriculture, $L P$ - price of agricultural land.

It is worth adding that the authors divided the determinants of agricultural income into three groups:

1. Micro: price paid, price received, TFP.

2. Meso: interest rate, exchange rate.

3. Macro: GDP and land prices.

Corresponding empirical econometric models were also estimated for these groups using the error correction model $(E C M)$ and the autoregressive distributed lag $(A D L)$ model, after which the authors performed a series of experiments using the impulse response function $(I R F)$. The source data was derived from the statistical series from 1964-2010 for agriculture and the US national economy. Considering this circumstance as a certain barrier to far-reaching generalizations, it is worth, however, bringing closer two key conclusions from the work by Beckman and Schimmelpfenning.

1. Admittedly, when introduced into only one model, all the identified categories affected agricultural income, although not always to a statistically significant degree. However, using separate models for the micro, meso, and macro levels enabled more thorough insight, as it made it possible to identify reciprocal impacts between the variables and the rate of adjustments to new equilibria, as well as short- and long-term elasticities.

2. As for the impulse response function, most of the relationships derived from the ECM and ADL models were generally confirmed, and thus, the prices paid by farmers, interest rates, and land prices reduced agricultural income. In turn, the prices obtained by farmers for products sold by them and GDP increased this income, while the exchange rate and TFP reduced income in the short term, increasing it, however, in the long term. Yet, the greatest - although not statistically significant - impact on income was exerted by the prices paid for supplies, 
especially in the short term. Overall, the elasticity of the long-run response to a shock in the case of prices paid was 4 times greater than to the same change (one standard deviation) in the price received.

Society may be interested in a fairer, i.e., more equal, distribution of income. It is very likely that lower-income groups have greater problems with smoothing their consumption over time. A modern system of social risk management should mitigate this constraint (Holzmann and Jorgensen, 2001). Consumption can be smoothed out by more conservative production and engaging labor, as well as by diversifying economic activity. However, the same aim may be accomplished through saving and borrowing, accumulation and release of physical assets, flexible adjustment of labor supply, and formal and informal risk transfers and risk sharing. These two mechanisms should result in improved smoother welfare of households, provided that the above-mentioned actions are fostered by an increase in the efficiency of all markets and public policy providing for, e.g., adequate transfer and tax instruments encouraging the saving and accumulation of physical, intellectual, and social capital. However, we must be aware that extremely poor people are characterized by exceptional risk aversion and may show specific non-linear behavior. As a consequence, they may engage in activities that generate little risk, but are also not profitable. This can make it difficult for them to get out of the poverty trap.

\section{Non-agricultural income}

In all analyses of agricultural income, we should refer to the concept of the household managing its agricultural activity. Relevant conceptual models should be based on the assumption that the optimal division of the family's working time between on-farm work, off-farm work, and leisure occurs when the marginal net value of the benefits from such time allocation is equal in each of these three groups of activities (Pandit, Pandel and Mishra, 2013). This is equivalent to the maximization by the farm operator or the spouse of the following utility function:

$$
U=U\left(I, L^{0}, L^{S}, C^{0}, C^{S}, \tau\right),
$$

with reduced operator's labor:

$$
T^{0}=L^{0}+y^{0}+F^{0},
$$

and that of the operator's spouse:

$$
T^{S}=L^{S}=y^{S}+F^{S} .
$$

The farm production function has the following formula:

$$
Y^{f}=f\left(F^{0}, F^{S}, X^{f}, C^{0}, C^{S}, R\right) .
$$

Finally, the farmer's household income is determined using the following formula:

$$
I=w^{0} y^{0}+w^{S} y^{S}+P_{f} Y_{f}-r_{f} X_{f}+V
$$


where: subscripts 0 and $S$ - refer to the farm operator and his/her spouse, $I$ - total income generalized to the net assets of the household, $L$ - leisure, $C$ - human capital that will be described in the empirical part using the number of years spent in all types of schools, $\tau$ - factors such as: phase of family and farm life cycle, the number of children, legal title to the farm, access to health insurance, $T$-total time resources, $Y$ - time allocated to off-farm work, $F$ - time allocated to on-farm work, $Y_{r}$ - farm's output, $X_{j}$ - inputs used on the farm, $R$ - location and characteristics of the farm (distance to urban areas, diversification, government payments), $w$ - wage rate in off-farm work, also described by the number of years of education in empirical analysis, $P_{f}$ - prices received for agricultural products sold, $R_{f}$ - prices of production inputs, $V$ - other non-household income, and thus obtained mainly in the form of various government subsidies. The aforementioned issues will be discussed later on in the paper.

\section{Dynamic approach to agricultural income}

In the context of modern risk management in agriculture, but not only, it is desirable to use an infinite time horizon of the dynamic model with savings, referred to by K. Farrin, M.J. Miranda, and E. O'Donoughue as a "multi-generation approach" (Farrin, Miranda, and O'Donoughue, 2016). Let us therefore outline its basic assumptions.

1. Suppose that "an infinitely lived farmer" begins each period endowed with predetermined wealth $\mathrm{w}$, which he or she must then allocate among consumption, savings, and purchase of insurance. In the subsequent period, the farmer faces an uncertain income $\tilde{y} \geq 0$ and an uncertain but insurable financial loss $1 \geq 0$ that is independent of income, with $E l \geq 0$. In order to preclude the possibility of non-positive wealth in any period, it has been assumed that: $y>1$, where: $y=\sup \{y \mid \operatorname{Pr}(\tilde{y} \leq y)=0\}$ is the greatest lower bound on attainable income, and: $l=\inf \{l \mid \operatorname{Pr}(l \geq 0)=1\}$ is the least upper bound on attainable losses. Of course, an infinitely lived farmer is a purely theoretical construct, but it is commonly used in intergenerational modeling. It should be understood as the lack of actual generational replacement in family farms.

2. The farmer may save wealth $s \geq 0$, earning a per-period interest rate $r>0$. The farmer may also insure the uncertain loss in the following period at a premium rate $\pi \geq 0$. This means that the one-off premium will be $x \pi$, while the compensation will be equal to $x l$, provided that the loss is $l$.

3. Now the farmer has to make the following decision: what savings rate $\mathrm{s}$ and insurance coverage $x$ he or she should choose in order to maximize the sum of the current and discounted expected future utility of consumption over an infinite horizon. Using R.E. Bellman's Principle of Optimality from 1957, this utility was characterized as a value function depending on the current wealth w, i.e., as $V(w)$ : 


$$
V(w)=\max _{s \geq 0, x \geq 0}\{u(w-s-\pi x)+\delta E V(\tilde{y}+(1+r) s-(1-x) l\}
$$

where: $\delta=(1+p)^{-1}$, whereby $p$ is the farmer's subjective discount rate; $u$ - utility of consumption, to be twice continuously differentiable, strictly increasing and strictly concave.

It can be seen that the utility of consumption is the resultant of the predetermined wealth, plus savings, less production and insurance costs. Furthermore, this utility is assumed to be isoelastic. This implies that:

$u(c)=c^{(1-\alpha)} /(1-\alpha)$, which also means that the farmer displays constant relative risk aversion (CRRA).

\section{Data sources and research methods}

The study covered commercial farms keeping agricultural accounting records as part of the Polish FADN from 2004-2018. A microeconomic approach was used in the paper to present the diversification of farm income in Poland. The analysis does not include entities whose production has practically no links to the market (these are self-supply farms), and the income generated by them from agricultural production is negligible (Goraj, Cholewa, Osuch, and Płonka, 2010), (Zawalińska, Majewski, and Wąs, 2015). The minimum economic size, above which an agricultural holding is included in the Polish FADN field of observation, is EUR 4,000 of Standard Output (SO) (in the case of Standard Gross Surplus (SGM), it was 2 ESU). The Polish FADN research sample consists of ca. 12 thousand farms and is representative of ca. 740 thousand commercial farms covered by the FADN field of observation (Floriańczyk, Osuch, and Płonka, 2019).

To show the ability of the analyzed farms to generate output and income, grouping by types of farming (TF8_), economic size classes (ES6), and FADN regions was used.

The same set of SO parameters (SO'2007) has been used to classify farms since 2013. This allows for the comparison of farms within agricultural types and economic size classes, while enabling the relation of the findings to the FADN field of observation. Therefore, in these two groupings, the timeframe was limited to 20132018. This approach makes it possible to apply appropriate weights to farms and compare the findings in selected groups of farms.

The analysis was based on the data from the database derived from "Wyniki Standardowe" (Standard Results) (Osuch et al. 2019), (RI/CC 882, Rev. 9. 2, 214). In this database, a uniform methodology applicable in all Member States is used to calculate particular variables. The analysis of non-farm income was carried out only for farms run by natural persons (Kambo, Juchniewicz, and Michalak, 2020).

The whole analysis was performed in current prices. Selected elements, i.e., production, costs, and income, are presented also in fixed prices. This data, as weighted averages, is representative of the field of observation of the Polish FADN. 
The income of the family farm was calculated using the method applicable in the Polish FADN. In accordance with the FADN methodology, family farm income is defined as the basic economic surplus obtained as part of the operating activity of the farm, that is at the farmer's disposal. It should provide remuneration for the involvement of own production inputs, i.e., the farmer's own labor and that of his or her family, land and capital, and ensure payment for the risks associated with running a farm (Floriańczyk et al., 2019; Goraj and Mańko, 2009; Mańko, 2015). A simplified diagram for calculating the financial performance of a farm is presented below. The categories used in the diagram correspond to the main concepts presented in the diagram of the family farm income calculation in the first part of "Wyniki Standardowe" (Standard Results) (Floriańczyk et al., 2019).

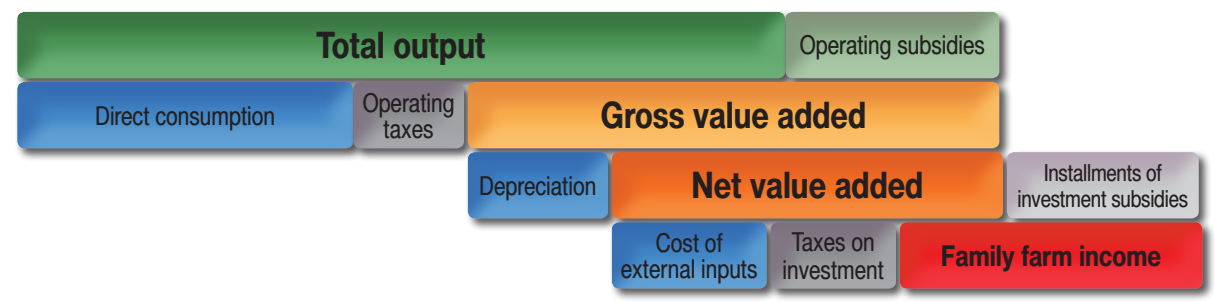

Fig. 1. Simplified diagram for calculating farm income.

Source: Mańko (2015), p. 65.

Income variability was calculated using the coefficient of variation. The analysis was carried out using the following indicators and measures:

- total output (SE131), total costs (SE270), direct costs (SE285), family farm income (SE420), total subsidies - excluding investment (SE605);

- family farm income/FWU (SE430);

- average annual net salary in the national economy ${ }^{1}$;

- ratio of total subsidies (excluding investment) to family farm income;

- ratio of subsidies to economic activity to output;

- ratio of SAP to family farm income;

- off-farm income ${ }^{2}$.

Family farm income (SE420), includes granted subsidies. This means that the farmer received a subsidy decision.

\footnotetext{
${ }^{1}$ The average annual net salary in the national economy was estimated by the Agricultural Holdings Accountancy Department based on the Polish Central Statistical Office (GUS) data and is published annually in Section II of the Standard Results regarding the analysis of Standard Results (Pawłowska-Tyszko, Osuch, and Płonka, 2020).

${ }^{2}$ Information on off-farm income has been systematically collected (through a survey) in farms keeping accounting records as part of the Polish FADN. The methodology and research findings are described annually in Poziom i struktura dochodów rodzin rolników w gospodarstwach prowadzacych rachunkowość w 2018 roku (e.g., Kambo et al., 2020).
} 


\section{Analysis of the findings}

The income situation (and thus the market position) of farms is affected by a number of external and internal factors.

Firstly, farms are located in a certain environment and operate in changing farming conditions. In order to achieve satisfactory results, they should efficiently and quickly respond to information coming from the market (in particular, the prices of agricultural products and production inputs). They should also be effectively managed to be able to generate the greatest possible income by adjusting the potential, scale, and structure of production and production costs, which will undoubtedly enable them to become competitive on the market.

Finally, they should take advantage of Poland's accession to the European Union. Poland's integration with the EU has undoubtedly enhanced opportunities regarding trade in agri-food products. Financial support for agriculture from the EU budget, in particular the European funds, was also launched, which has also influenced the income generated by Polish farms.

Nowadays, a threat is the rapidly changing climate and ever more intense weather anomalies accompanying climate change, as well as deteriorating natural conditions, which increases the economic risk of farms.

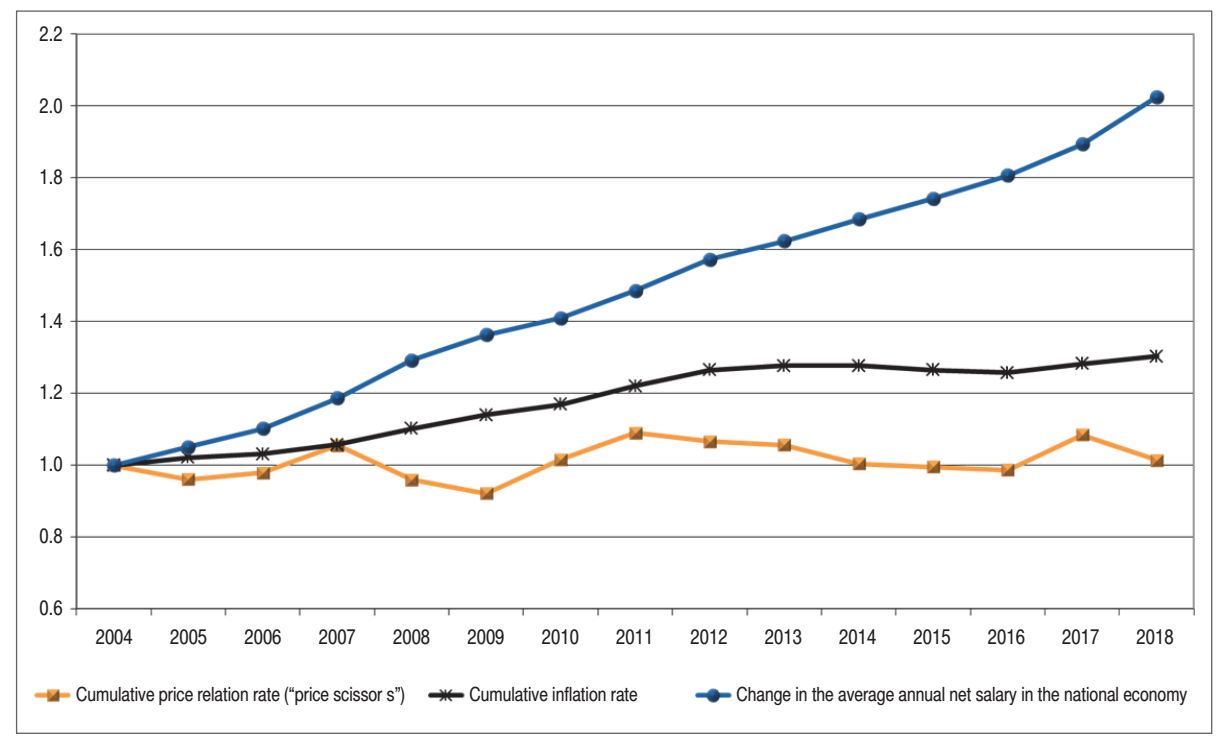

Fig. 2. Development of selected macroeconomic ratios from 2004-2018.

Source: own study based on data from the Polish Central Statistical Office (GUS) and calculations made by the Agricultural Holdings Accountancy Department.

As for the analyzed period of 2004-2018, it can be said that the macroeconomic conditions were the most favorable in 2007, 2011, and 2017 (Figure 2). The worst period was at the time of the economic crisis (2008-2009). From 2012 to 2016, 
the situation also deteriorated compared to the very favorable 2011, as undoubtedly evidenced by the development of a price scissors index. There was also an increase in inflation (a slowdown from 2013-2016) and an increase in the rate of growth of net salaries, in particular in 2018 compared to 2017 . The average annual net salary in the national economy increased by over 100\% compared to 2004 (from PLN 18.3 to PLN 37.2 thousand). The influence of these factors on the performance of the analyzed farms is shown in Figure 3.

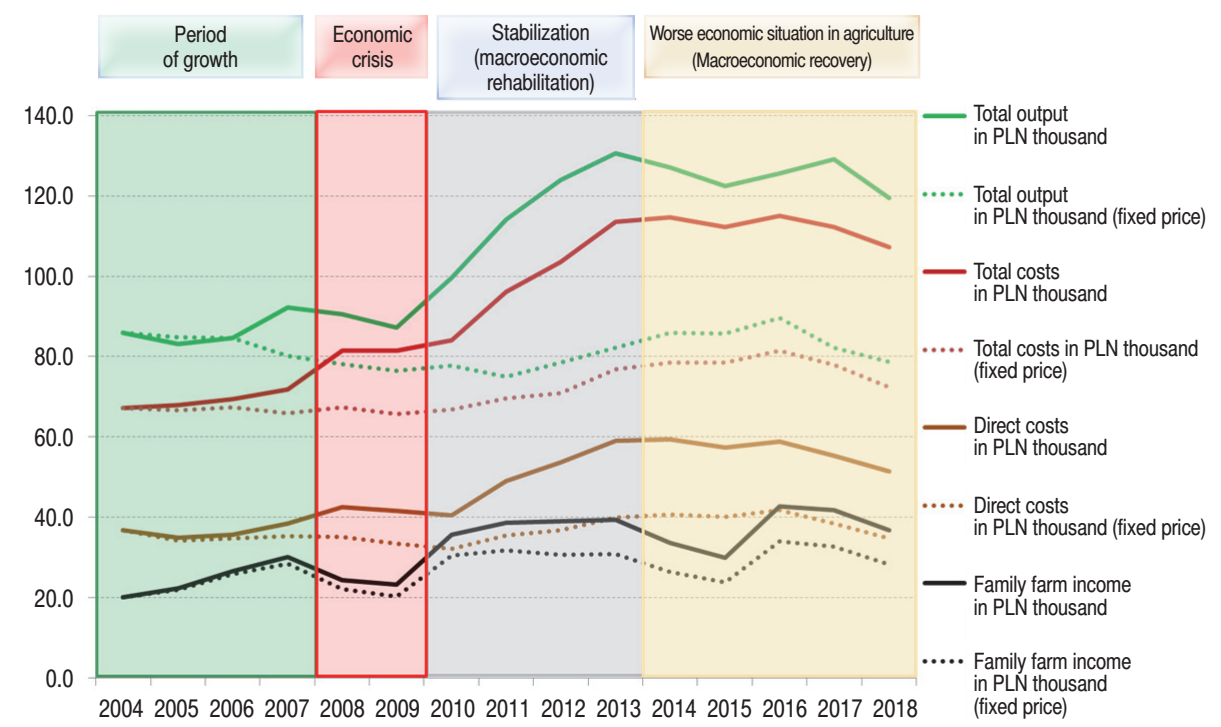

Fig. 3. Financial performance of farms in the field of observation of the Polish FADN from 2004-2018 per farm (current and fixed prices).

Source: own study based on data from the Polish FADN.

In the field of FADN observation are potentially commercial farms whose output is intended for the market. These farms are very diverse in terms of types of farming and economic size. Most farms represent the mixed type (45\%) and the field crop type (ca. 24\%). For the vast majority of farms (almost 93\%), the economic size did not exceed EUR 50 thousand (Pawłowska-Tyszko et al., 2020). In fact, the field of observation of the Polish FADN concerns small farms, which is due to the structure of farms in Poland (Goraj et al., 2010; Goraj, Osuch, Bocian, Cholewa, and Malanowska, 2012). The situation in these farms determines the economic situation of commercial agriculture in Poland.

The output value in current prices in the period considered was affected mainly by the market situation. In 2007, as well as from 2010 to 2013 and in 2017, there was a dynamic increase in the prices of plant products and milk. As a result, the output value grew in those years to reach the highest level in 2013. Its lowest values were recorded at the beginning of the analyzed period, i.e., from 2004 to 2006, 
which is obvious, as farms had to adapt their capacities and scale of production to the new farming conditions. In 2009, its value decreased due to the economic crisis.

Output at fixed prices would decrease until 2011. Its growth was recorded only from 2012 to 2016 as a result of the favorable situation in the market and higher cereal prices, which undoubtedly encouraged farmers to increase their output.

Total costs in nominal terms grew at different rates in the analyzed period, until they reached a halt and began to decline in 2014 (except for 2016). In real terms, costs would increase (except for 2007-2009 and 2017-2018). What seems disturbing is the reduction in direct costs after 2008 to 2010 and no increases therein from 2013, both in nominal and real terms. This means that farmers cut down on the costs that determine the output volume.

As for family farm income, its value, both in nominal and real terms, increased rapidly between 2005 and 2007 and from 2010, while its significant decreases were recorded from 2008-2009 and 2014-2015. The most favorable financial situation of the analyzed farms throughout the period concerned, both in current and fixed prices, was in 2016, despite the deteriorating macroeconomic conditions. This was due to the accumulation of subsidies from previous periods.

Summing up this part of the considerations, it can be said that the financial situation of the analyzed farms was largely dependent on the macroeconomic conditions. The financial performance of farms was affected mainly by the price growth rate concerning production inputs and agricultural products.

Based on the results achieved and the conditions that prevailed over the last 15 years, an attempt to define the periods in which the farms operated was made (this is, of course, a suggestion):

1. The first period - called the period of growth, adaptation, and learning.

2. The second period - the economic crisis (the worst performance throughout the period concerned).

3. The third period - some macroeconomic/income stabilization. It can be said to be the period of rehabilitation. In this period, the farms' performance was the best.

4. The last, the fourth period - worse economic situation in agriculture, accompanied by recovery in the macroeconomic environment.

\section{Influence of the production type and economic size of FADN farms on their income}

To show the ability of the analyzed farms to generate output and income (as already mentioned), grouping by types of farming (TF8_), economic size classes (ES6), and FADN regions was used (Figure 4). 

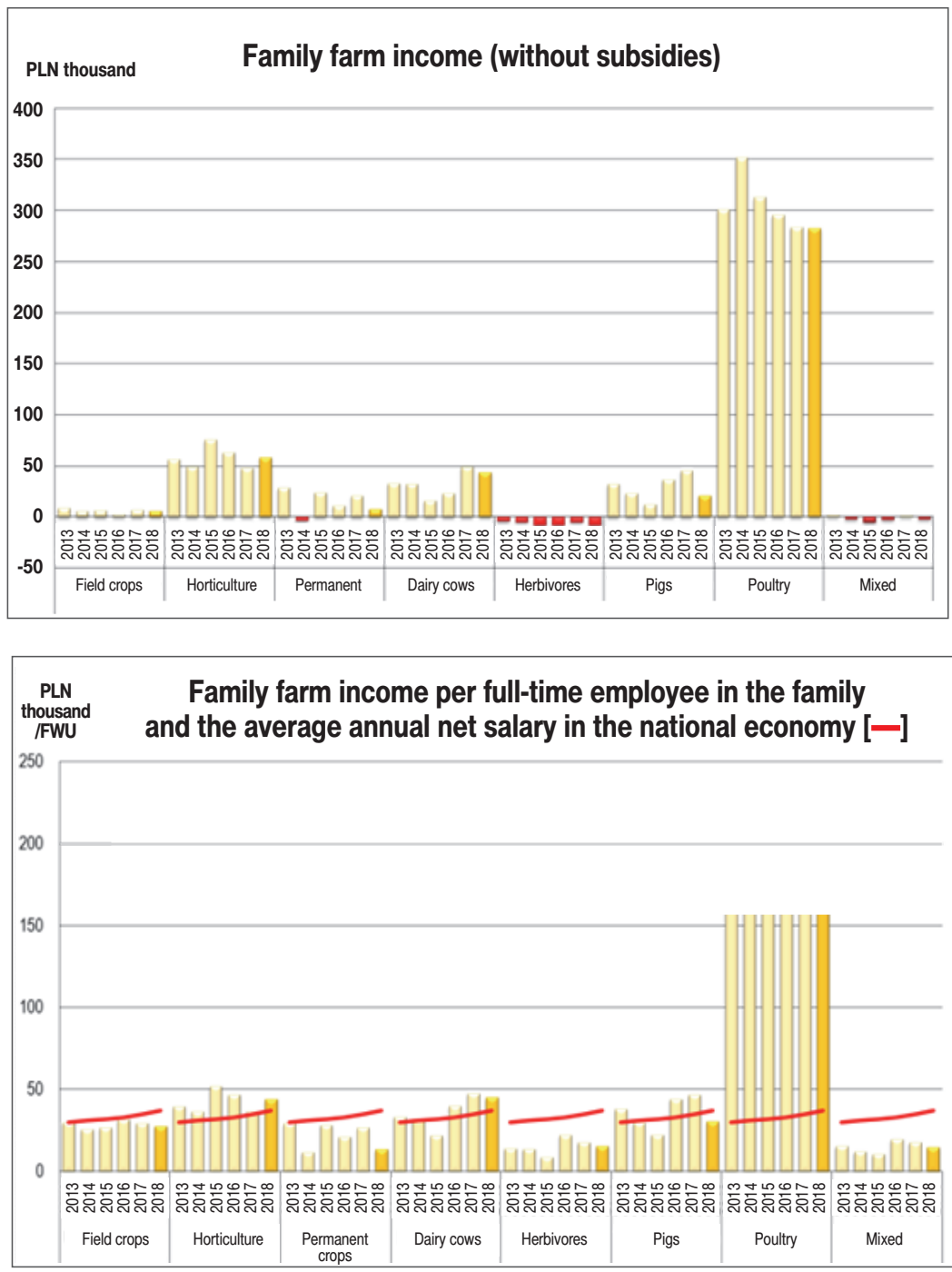

Fig. 4. Family farm income without subsidies (average per farm) and family farm income per full-time employee in the family and the average annual net salary in the national economy on farms in the field of observation of the Polish FADN from 2013-2018 classified by types of farming.

Source: own study based on data from the Polish FADN.

In the case of farms grouped by type of farming, attention should be paid to farms strongly connected with land (field crops, farms with herbivores, and mixed crops) that operate, one could say, thanks to subsidies. Were it not for subsidies, they would incur losses or their income would be very low. In the case of these farms, the average amount of family farm income per full-time employee in the family (from PLN 9 thousand to PLN 32 thousand) was lower than the average annual net 
salary in the national economy (from PLN 29.8 thousand to PLN 37.2 thousand). Only farms that can operate without land (poultry) are able to generate very high income.

Farms also changed the organization of production through a higher level of specialization. For example, there was a decrease in the number of mixed farms in favor of those specializing in field crops. Farms also reacted to signals from the market, deciding in some cases to change the production attitude, from less to more profitable, or the production scale (Płonka, 2019).

Farm specialization means also:

- higher income,

- reduced dependence on budget support (pig, poultry, dairy, and horticultural farms - these farms generate higher incomes than the average annual net salary in the national economy).

Specialization also implies a greater risk, as in the case of farms specializing in permanent crops, that after the introduction of the Russian embargo on imported products, also from Poland, incurred severe losses.

In the era of ongoing changes in nutrition (e.g., a decrease in meat consumption per capita in Poland) and EU measures aimed at climate neutrality, the income of farms specializing in livestock production may be under greater pressure in the future.

Where farms are grouped by economic size class, it is worth paying attention to the smallest (family/hobby) and the largest (based on hired labor) farms that have to rely on subsidies to cover all their costs and to generate an economic surplus (Figure 5).

It is tempting to say that for families running very small farms, agriculture is a secondary activity, because most of their income is generated off-farm (Kulawik, Płonka, and Wieliczko, 2020; Kambo et al., 2020). Satisfactory farm income can be generated by medium-small and larger entities. Therefore, agricultural policy should favor an evolution towards increasing the economic strength of farms. The above conclusion is also confirmed by the fact that income higher than the average annual net salary in the national economy was generated by farms in economic size classes with SO above EUR 25,000, whose share in the field of observation in 2018 was only $20 \%$. Other researchers' views that adequate resources of land and other production inputs are necessary for farms to generate satisfactory income may be therefore reaffirmed (Sobczyński, 2018). 

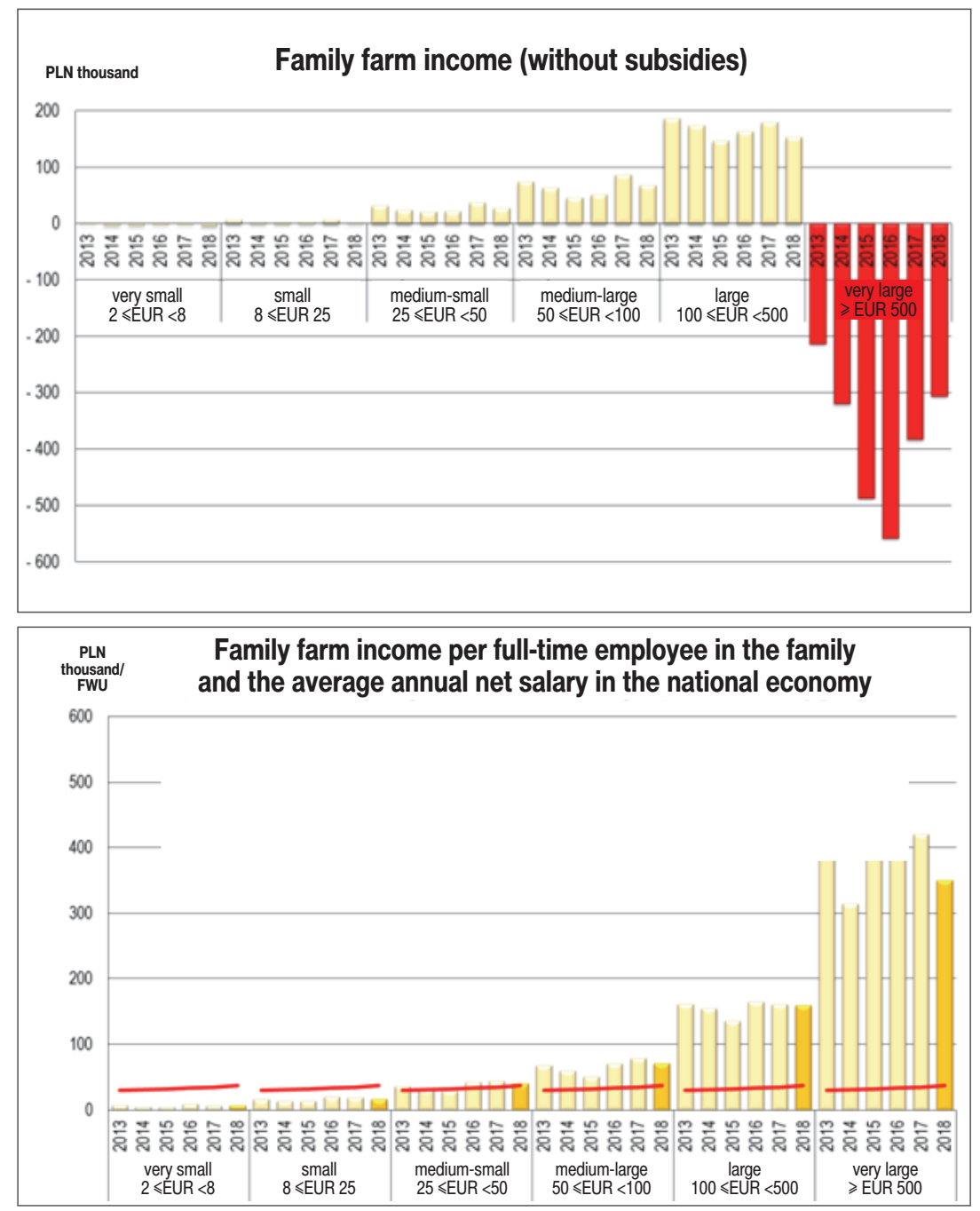

Fig. 5. Family farm income without subsidies (average per farm) and family farm income per full-time employee in the family and the average annual net salary in the national economy on farms in the field of observation of the Polish FADN from 2013-2018 classified by economic size class. Source: own study based on data from the Polish FADN.

\section{Off-farm income and spatial differentiation of income}

Although generating non-agricultural income stabilizes the total risk of farmers' households, it may increase the riskiness of the agricultural activity itself. Nonagricultural income is an important item in the budgets of small farms in Poland (Zawalińska et al., 2015, p. 354). The situation is similar, for example, in Ireland (Loughrey and Hennessy, 2016) and the United States (Key, Prager, and Burns, 
2018), where $45 \%$ of farm operators worked in 2016 off-farm, and $75 \%$ of them worked full-time off-farm (El-Osta, 2020, p. 453). The significance of this income for the analyzed population is shown in Figure 6.

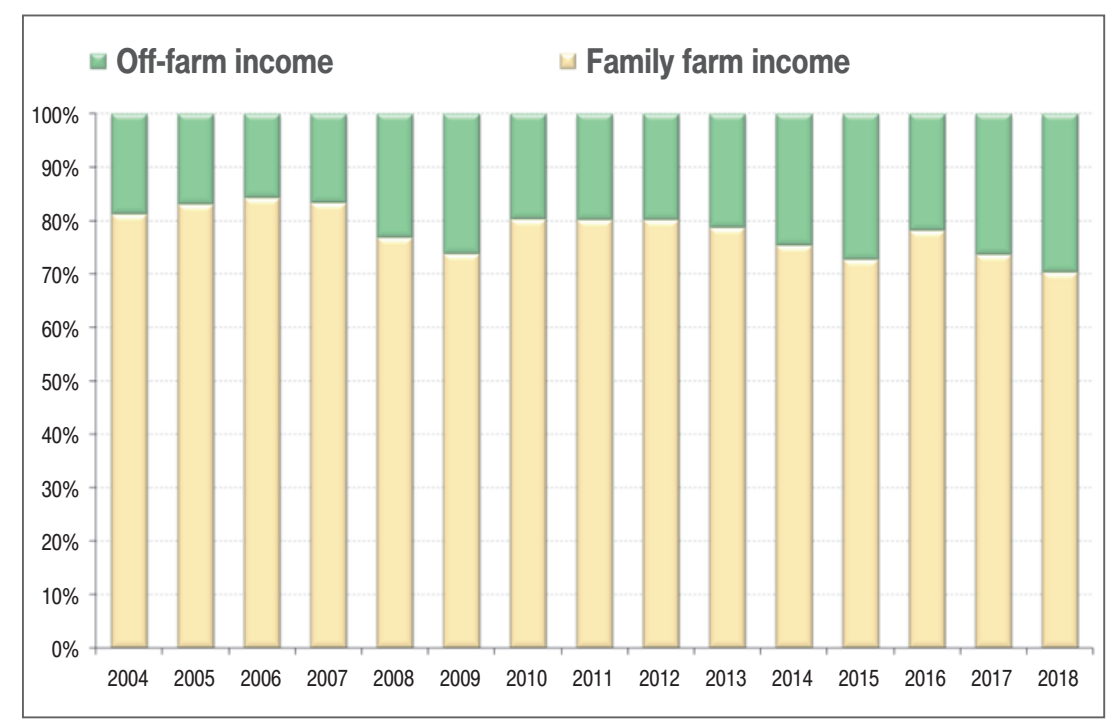

Fig. 6. The structure of the farmer's family income in farms in the field of observation of the Polish FADN from 2004-2018 (average per farm).

Source: own study based on data from the Polish FADN.

Between 2004 and 2018, the total output value increased significantly in all Polish FADN regions, except for Małopolska and Pogórze, where this increase was insignificant (Figure 7). Differences in the output volume translate into the income level and the competitiveness of farms in particular regions. Differences in the production scale result from different sizes and production structures of farms.

These differences did not change in the analyzed period, which means that agriculture in particular regions of Poland develops according to its own growth paths. The largest scale of production, and thus also the highest income of farms, is reported in Pomorze and Mazury. This region was also the one with the greatest share of subsidies in family farm income (Figure 7).

In the analyzed period, three sub-periods corresponding to the EU programming periods, each of which introduced smaller or bigger changes to the form and scale of support for agriculture in the EU, can be identified. In all Polish FADN regions, in each subperiod, the direction of changes in the level of farm income, operating payments, and income reduced by them, was the same. The scale of the changes was, however, different. 


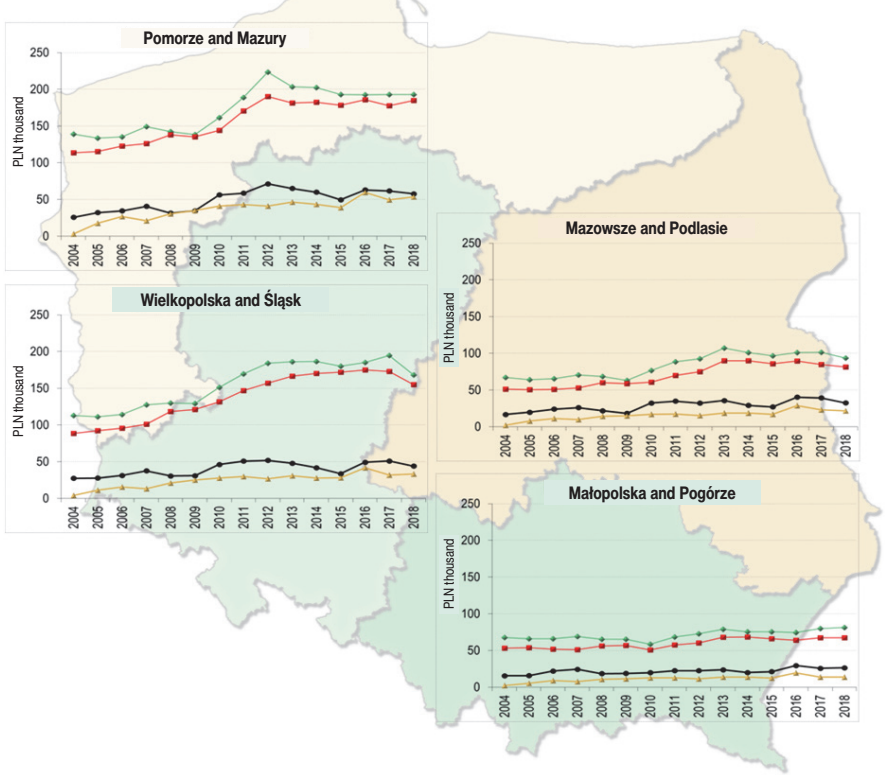

Fig. 7. Total output [-], total costs [-], family farm income [-] operating subsidies [-] in PLN thousand on commercial farms in the FADN regions from 2004-2018 (average per farm).

Source: own study based on data from the Polish FADN.

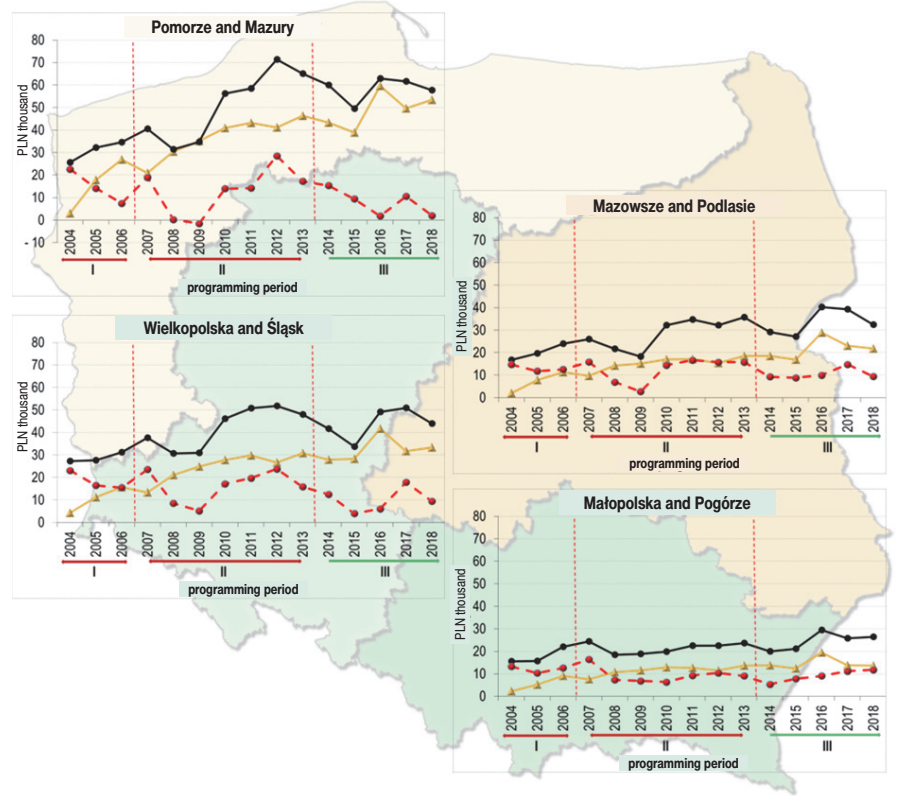

Fig. 8. Family farm income [-], operating subsidies [- ], and family farm income (without subsidies) $[-]$ in PLN thousand on commercial farms in the FADN regions from 2004-2018 (average per farm). Source: own study based on data from the Polish FADN. 
The importance of public support for family farm income varies from region to region. The greatest income spread in the analyzed period was recorded in Pomorze and Mazury. It was also the only region where negative family farm income without subsidies was recorded. The smallest spread in family farm income was recorded in farms in Małopolska and Pogórze (Figure 8).

The ratio of farming subsidies to income shows an even more profound differentiation of the support impact on the income situation of farms in particular regions. In Pomorze and Mazury, this ratio from 2007-2018 was, on average, ca. $80 \%$. In Wielkopolska and Śląsk, it was ca. 70\%, in Mazowsze and Podlasie- over $60 \%$ (with significant fluctuations), while in Małopolska and Pogórze - ca. 60\%, with little variability in this ratio (Figure 9).

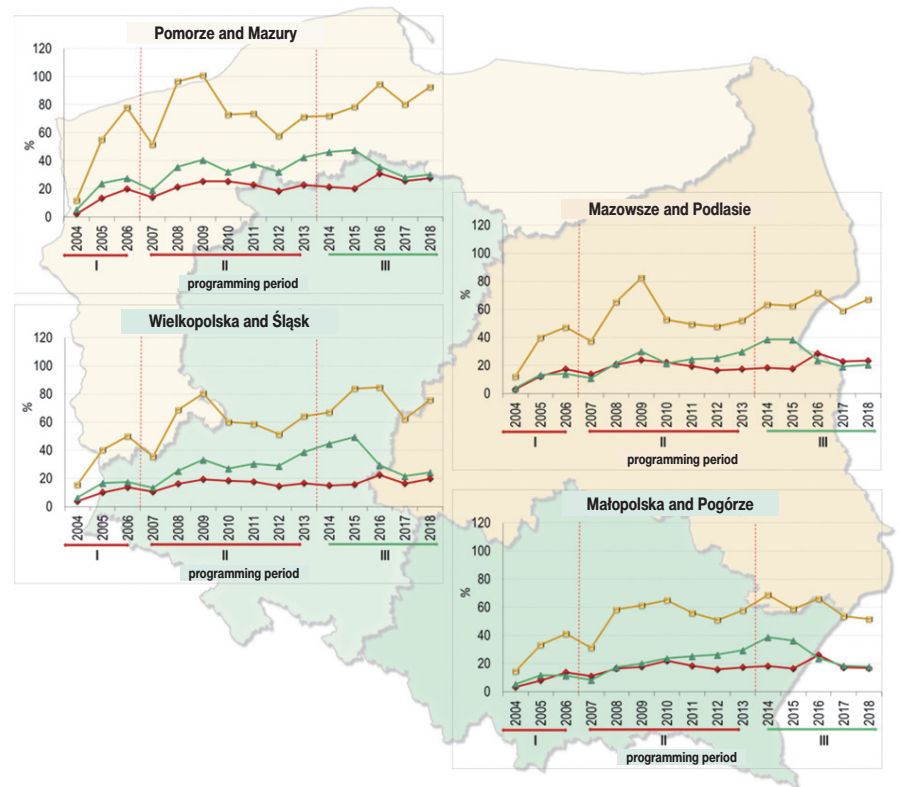

Fig. 9. The ratio of farming subsidies to family farm income [-], to output $[-]$, and the ratio of SAP to family farm income [-] in \% on commercial farms in the FADN regions from 2004-2018 (average per farm).

Source: own study based on data from the Polish FADN.

Comparison of family farm income per full-time employee in the family and the average annual net salary in the national economy shows the actual income situation of farming families. In Pomorze and Mazury, income was higher than the average salary in the national economy for over half of the analyzed period. In Wielkopolska and Śląsk, agricultural income was higher than in the national economy for less than half of the analyzed period. In the other two regions, agricultural income was significantly lower throughout the period concerned. The lowest income was generated in Małopolska and Pogórze, where on average, it was only half of the average income in the national economy (Figure 10). 


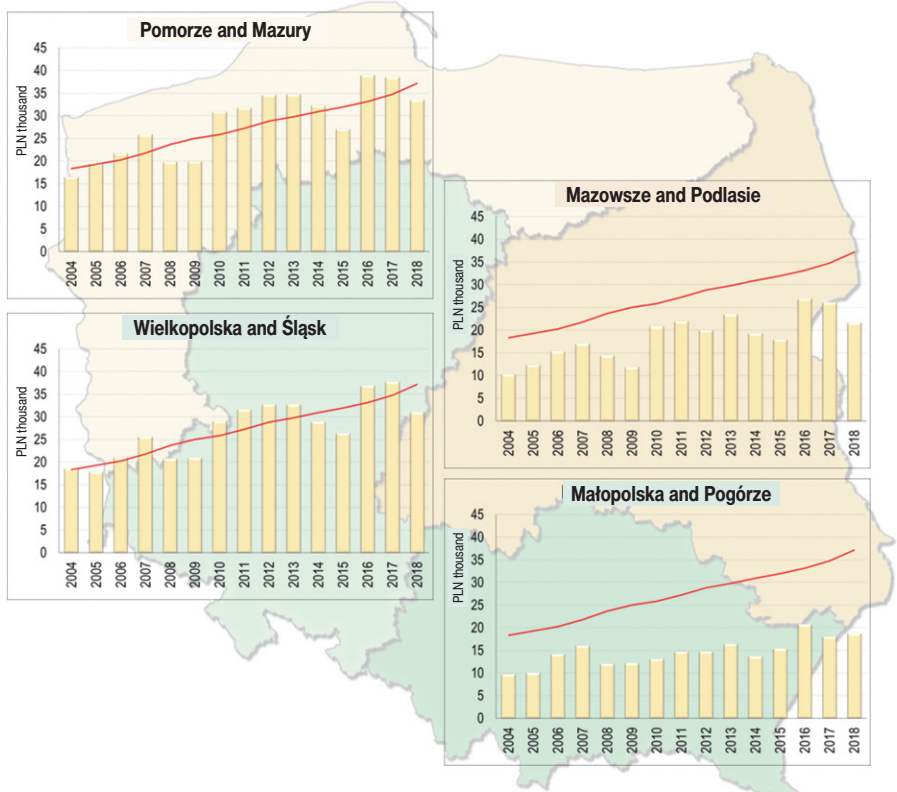

Fig. 10. Family farm income per full-time employee in the family and the average annual net salary in the national economy [-] in PLN thousand on commercial farms in the FADN regions from 2004-2018 (average per farm).

Source: own study based on the Polish FADN data.

The analysis of the family farm income level by region also shows that the scale of income differentiation is different in particular regions. The greatest differences, measured by the coefficient of variation, were recorded in the analyzed period in Pomorze and Mazury, while the smallest ones were found in Małopolska and Pogórze, which is due to the different structure of agriculture in these regions.

\section{Interchangeability between risk and income}

The family farm income level is extremely diversified within particular regions, types of farming, and economic size classes (Table 2). The greatest differences in the income level occur in Pomorze and Mazury, where the largest number of very large farms are located. The smallest differences are found in Mazowsze and Pogórze. As for production types, the greatest differences in the income level are found on farms with mixed production, while the smallest ones are on farms with dairy cows and poultry. Small differences in the income level are recorded also on medium-small and medium-large farms, while the largest ones are found on very large farms. 
Income risk diversification measured by the coefficient of variation

Table 2

\begin{tabular}{|c|c|c|c|c|c|c|c|c|c|c|c|c|c|c|c|}
\hline \multirow{2}{*}{ Item } & \multicolumn{15}{|c|}{ Years } \\
\hline & 2004 & \multicolumn{2}{|c|}{20052006} & \multirow{2}{*}{$\begin{array}{c}2007 \\
282\end{array}$} & \multirow{2}{*}{$\frac{2008}{287}$} & \multirow{2}{*}{$\frac{2009}{303}$} & \multirow{2}{*}{$\frac{2010}{254}$} & \multirow{2}{*}{$\begin{array}{c}2011 \\
267\end{array}$} & \multirow{2}{*}{$\frac{2012}{332}$} & \multirow{2}{*}{$\frac{2013}{305}$} & \multirow{2}{*}{$\frac{2014}{335}$} & \multirow{2}{*}{$\frac{2015}{405}$} & \multirow{2}{*}{$\frac{2016}{268}$} & \multirow{2}{*}{$\begin{array}{r}2017 \\
270\end{array}$} & \multirow{2}{*}{$\frac{2018}{283}$} \\
\hline Farms in total & 290 & 309 & 245 & & & & & & & & & & & & \\
\hline \multicolumn{16}{|l|}{ FADN regions } \\
\hline $\begin{array}{l}\text { Pomorze } \\
\text { and Mazury }\end{array}$ & 390 & 371 & 385 & 372 & 334 & 353 & 289 & 330 & 338 & 307 & 351 & 382 & 278 & 303 & 350 \\
\hline $\begin{array}{l}\text { Wielkopolska } \\
\text { and Śląsk }\end{array}$ & 264 & 347 & 228 & 302 & 315 & 286 & 263 & 271 & 345 & 332 & 311 & 493 & 307 & 302 & 266 \\
\hline $\begin{array}{l}\text { Mazowsze } \\
\text { and Podlasie }\end{array}$ & 233 & 190 & 165 & 195 & 211 & 245 & 173 & 180 & 217 & 238 & 269 & 287 & 217 & 185 & 206 \\
\hline $\begin{array}{l}\text { Małopolska } \\
\text { and Pogórze }\end{array}$ & 282 & 270 & 218 & 212 & 274 & 284 & 220 & 199 & 239 & 281 & 340 & 391 & 223 & 245 & 254 \\
\hline \multicolumn{16}{|l|}{ Types of farming } \\
\hline Field crops & & & & & & & & & & 295 & 371 & 369 & 280 & 312 & 311 \\
\hline Horticulture & & & & & & & & & & 260 & 316 & 262 & 222 & 149 & 165 \\
\hline Permanent crops & & & & & & & & & & 248 & 410 & 265 & 210 & 223 & 322 \\
\hline Dairy cows & & & & & & & & & & 127 & 133 & 160 & 110 & 116 & 127 \\
\hline Herbivores & & & & & & & & & & 189 & 181 & 347 & 140 & 164 & 204 \\
\hline Pigs & & & & & & & & & & 287 & 255 & 264 & 208 & 204 & 233 \\
\hline Poultry & & & & & & & & & & 165 & 130 & 127 & 131 & 106 & 125 \\
\hline Mixed & & & & & & & & & & 388 & 367 & 711 & 353 & 384 & 376 \\
\hline \multicolumn{16}{|l|}{$\begin{array}{l}\text { Economic size } \\
\text { classes }\end{array}$} \\
\hline Very small $2 \leq$ EUR $<8$ & & & & & & & & & & 123 & 172 & 203 & 150 & 203 & 234 \\
\hline Small $8 \leq$ EUR $<25$ & & & & & & & & & & 108 & 129 & 145 & 94 & 111 & 131 \\
\hline $\begin{array}{l}\text { Medium-small } \\
25 \leq \mathrm{EUR}<50\end{array}$ & & & & & & & & & & 79 & 90 & 118 & 72 & 79 & 86 \\
\hline $\begin{array}{l}\text { Medium-large } \\
50 \leq \text { EUR }<100\end{array}$ & & & & & & & & & & 73 & 91 & 90 & 68 & 67 & 78 \\
\hline Large $100 \leq$ EUR $<500$ & & & & & & & & & & 130 & 142 & 147 & 121 & 101 & 119 \\
\hline Very large EUR $\geq 500$ & & & & & & & & & & 406 & 254 & 1170 & 1325 & 551 & 252 \\
\hline
\end{tabular}

Source: own study based on data from the Polish FADN.

The comparison of the income level per full-time employee and the coefficient of income variation for particular types of farming shows a very large differentiation in the situation of particular groups of farms (Figure 11). These two variables position particular groups of farms differently also in terms of economic size classes, which proves their varied income situation (Figure 12). 


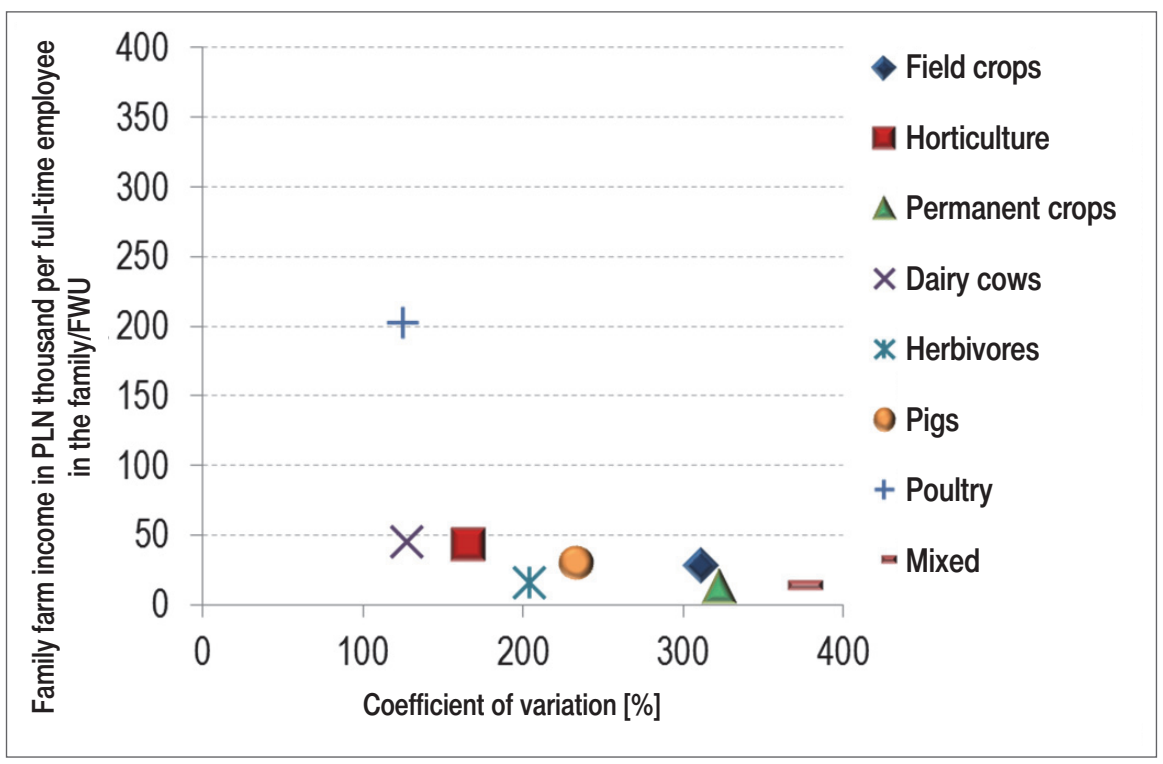

Fig. 11. Income per person and coefficient of income variation vs. type of farming. Source: own study based on data from the Polish FADN.

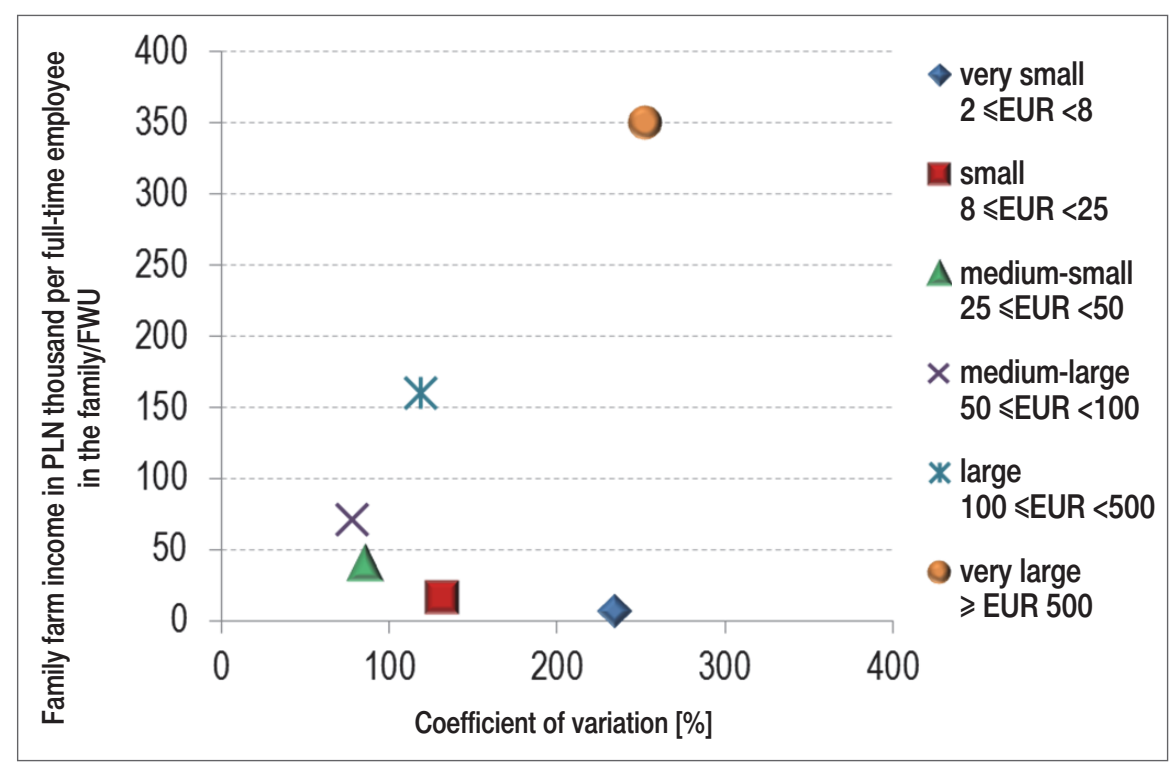

Fig. 12. Income per person and coefficient of income variation vs. economic size class in EUR thousand.

Source: own study based on data from the Polish FADN. 


\section{Conclusions}

- On the one hand, the impact of agricultural support systems stabilizes the income level but, on the other hand, makes farmers dependent on decisions made at the national and EU levels with regard to agriculture financing. If it were not for the common agricultural policy, some farms would be unprofitable. It should be mentioned, however, that there are farms that are effectively managed and are doing well in the market, even without subsidies. However, these are farmers, as emphasized also by other researchers, that constitute the main group of direct and indirect beneficiaries of Poland's accession to the EU.

- As for the production type, an increase in specialization increases the income level and reduces dependence on budget support (horticultural, pig, poultry, and dairy farms), but can lead to greater risks, including the exogenous type (political/institutional).

- In terms of economic size class, income greater than the average annual net salary in the national economy was generated by farms in economic size classes with SO above EUR 25 thousand, whose share in the field of observation in 2018 was only $20 \%$. The smallest (self-supply/hobby) and the largest (based on hired labor) farms have to rely on subsidies to be able to cover all of their costs and to generate an economic surplus.

- Regional differences in the level of family farm income, as well as family farm income per full-time employee in the family prevail. The policy tools applied to the agricultural sector seem to be neutral for the scale of regional differences in the level of income in the agricultural sector. 


\section{References}

Baek, J., Koo, W. (2010). The US Agricultural Sector and the Macroeconomy. Journal of Agricultural and Applied Economics, Vol. 42, No. 3.

Barry, P.J., Escalante, C.L., Bard S.K. (2001). Economic Risk and the Structural Characteristics of Farm Business. Agricultural Finance Review, Vol. 61, No. 1.

Beckman, J., Schimmelpfenning, D. (2015). Determinants of Farm Income. Agricultural Finance Review, Vol. 75, No. 3.

Bellman, R. (1957). Dynamic Programming. New Jersey: Princeton University Press.

Binswanger-Mkhize, H.P. (2012). Is There Too Much Hype About Index-Based Agricultural Insurance?. Journal of Development Studies, Vol. 48, No. 2.

Boehlje, M., Gloy, B., Henderson, J. (2013). US Farm Prosperity: the New Normal or Reversion to the Mean. American Journal of Agricultural Economics, Vol. 95, No. 2.

El Benni, N., Finger, R., Meuwissen, M.P.M. (2016). Potential Effects of the Income Stabilisation Tool (IST) in Swiss Agriculture. European Review of Agricultural Economics, Vol. 43, No. 3.

El-Osta, H.S. (2020). The Rural-Urban Income Divide Among Farm Households: the Role of Off-Farm Work and Farm Size. Agricultural Finance Review, No. 80, pp. 453-470.

Farrin, K., Miranda, J.M., O’Donoughue, E. (2016 August). How Do Time and Money Affect Agricultural Insurance Uptake? A New Approach to Farm Risk Mamagement Analysis, USDA, ERS, Washington.

Floriańczyk, Z., Osuch, D., Płonka, R. (2019). Wyniki Standardowe 2018 uzyskane przez gospodarstwa rolne uczestniczace w Polskim FADN. Część I. Warszawa: IERiGŻ-PIB.

Goraj, L., Cholewa, I., Osuch, D., Płonka, R. (2010). Analiza skutków zmian we Wspólnotowej Typologii Gospodarstw Rolnych. Warszawa: IERiGŻ-PIB.

Goraj, L., Mańko, S. (2009). Rachunkowość i analiza ekonomiczna w indywidualnym gospodarstwie rolnym. Warszawa: Difin.

Goraj, L., Osuch, D., Bocian, M., Cholewa, I., Malanowska, B. (2012). Plan wyboru próby gospodarstw rolnych Polskiego FADN od roku obrachunkowego 2013. Warszawa: IERiGZ̈-PIB.

Grzelak, M.M. (2016). Dochody rozporządzalne gospodarstw rolnych na tle dochodów innych grup społeczno-ekonomicznych w Polsce w latach 2003-2014. Annales Universitatis Mariae Curie-Skłodowska Lublin-Polonia, Vol. L.4, section H.

Holzmann, R., Jorgensen, S. (2001). Risk Management: A New Conceptual Framework for Social Protection, and Beyond. International Tax and Public Finance, Vol. 8.

Jones, R. (1969). Stability in Farms Incomes. Journal of Agricultural Economics, Vol. 20, No. 1.

Kambo, K., Juchniewicz, M., Michalak, P. (2020). Poziom i struktura dochodów rodzin rolników w gospodarstwach prowadzacych rachunkowość w 2018 roku. Warszawa: IERiGŻ-PIB.

Kulawik, J., Płonka, R., Wieliczko, B. (2020). Zmiany sytuacji dochodowej gospodarstw rolnych z pola obserwacji Polskiego FADN w latach 2004-2018. Konferencja: Stan i perspektywy rozwoju wsi i rolnictwa - 70 lat IERiGŻ-PIB. Warszawa.

Key, N., Prager, D.L., Burns, B. (2018). The Income Volatility of U.S. Commercial Farm Households. Applied Economic Perspectives and Policy, 40, s. 215-239. DOI:10.1093/aepp/ppy006.

Loughrey, J., Hennessy, T. (2016). Farm Income Variability and Off-Farm Employment in Ireland. Agricultural Finance Review, Vol. 76, No. 3.

Mańko, S. (2015). Analiza ekonomiczna $w$ indywidualnym gospodarstwie rolnym. Minikowo: Kujawsko-Pomorski Ośrodek Doradztwa Rolniczego w Minikowie.

Mishra, A.K., Sandretto, L.C. (2002). Stability of Farm Income and the Role of Nonfarm Income in U.S. Agriculture. Review of Agricultural Economics, Vol. 24. 
Pandit, M., Pandel, K.P., Mishra, A.K. (2013). Do Agricultural Subsidies Affect the Labor Allocation Decision? Comparing Parametric and Semiparametric Methods. Journal of Agricultural and Resource Economics, Vol. 38, No. 1.

Osuch, D., Bocian, M., Cholewa, I., Juchnowska, E., Smolik, A., Płonka, R. (2019). Najważniejsze informacje niezbędne do interpretacji wyników Polskiego FADN. Warszawa: IERiGŻ-PIB. Retrieved from z: http://fadn.pl/wp-content/uploads/metodyka/Najwazniejsze-informacje.pdf).

Pawłowska-Tyszko, J., Osuch, D., Płonka, R. (2020). Wyniki Standardowe 2018 uzyskane przez gospodarstwa rolne uczestniczace w Polskim FADN. Część II. Analiza Wyników Standardowych. Warszawa: IERiGŻ-PIB.

Płonka, R. (2019). Sytuacja ekonomiczna gospodarstw rolnych z pola obserwacji Polskiego FADN w latach 2004-2018. 17. Krajowe warsztaty organizacyjno-szkoleniowe Polskiego FADN, Serwy.

Poon, K., Weersink, A. (2011). Factors Affecting Variability in Farm and Off-Farm Income. Agricultural Finance Review, Vol. 71, No. 3.

RI/CC 882 Rev.9.2 Definitions of Variables Used in FADN Standard Results. European Commission, Brussels December 2014.

Sinn, H.W. (1986). Risiko als Produktionsfaktor. Jahrbücher für Nationalökonomie und Statistik.

Sobczyński, S. (2018). Zmienność dochodów gospodarstw rolnych będzie narastać. Material summarizing the conference ,Tendencje oraz czynniki zmienności dochodów gospodarstw rolniczych w województwie kujawsko-pomorskim na tle Polski i Unii Europejskiej”. Retrieved from: https://www.kpodr.pl/zmiennosc-dochodow-gospodarstw-rolniczych-bedzie-narastac/, KPODR w Minikowie.

Walters, C., Preston, R. (2018). Net Income Risk, Crop Insurance and Hedging. Agricultural Finance Review, Vol. 78, No. 1.

Woś, A. (1987). Podstawy nauki o polityce rolnej. Warszawa: Państwowe Wydawnictwo Rolnicze i Leśne.

Woś, A. (red.). (1998) Encyklopedia agrobiznesu. Warszawa: Fundacja Innowacja.

Zawalińska, K., Majewski, E., Wąs, A. (2015). Długookresowe zmiany w dochodach z polskiego rolnictwa na tle krajów Unii Europejskiej. Roczniki Naukowe SERiA, Vol. XVII, Issue 6, pp. 346-354. 


\title{
ZMIANY SYTUACJI DOCHODOWEJ \\ GOSPODARSTW ROLNYCH Z POLA OBSERWACJI \\ POLSKIEGO FADN W LATACH 2004-2018
}

\begin{abstract}
Dochody rolników $i$ ich rodzin sq podstawa konsumpcji, oszczędności i inwestycji. Jednak poza ich poziomem i odpowiednimi relacjami do dochodów ludności rolniczej ważna jest także ich stabilność. Ta właśnie teza jest główna osia analizy ksztattowania się sytuacji dochodowej polskich rolników uczestniczacych w sieci FADN w latach 2004-2018. Jej udokumentowanie jest zarazem głównym celem artykułu. By uczynić to w odpowiedniej perspektywie teoretycznej, w poczatkowej części artykułu przedstawiono schematy ich obliczania oraz ich determinanty, a także kwestie zwiazane z mierzeniem ryzyka dochodowego i czynniki na nie wptywajace. Zastosowano tu podejście statyczne oraz dynamiczne. W drugiej, na wskroś empirycznej i retrospektywnej części artykułu skoncentrowano się na zależnościach między dochodami a wsparciem budżetowym, wielkościq ekonomiczna, typem produkcyjnym i położeniem gospodarstw w przestrzeni. Dodatkowo pokazano znaczenie dochodów pozarolniczych, aczkolwiek informacje na ten temat w FADN nie sq zbyt bogate. Jako ujęcie wstepne problemu należy też potraktować identyfikację strategii ryzyko-dochody.
\end{abstract}

Słowa kluczowe: dochody rolnicze, rolnictwo, ryzyko dochodowe.

Accepted for print: 21.12.2020.

Unless stated otherwise all the materials on the website are available under the Creative Commons Attribution 4.0 International license.

Some rights reserved to the Institute of Agricultural and Food Economics - National Research Institute.

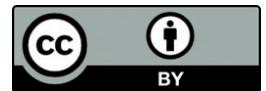

